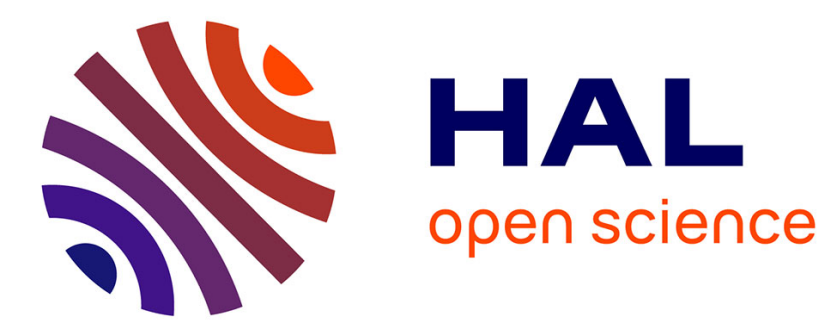

\title{
Skill-induced Mobilization at Work: a Study of an Activist Group
}

Fabien Hildwein

\section{To cite this version:}

Fabien Hildwein. Skill-induced Mobilization at Work: a Study of an Activist Group. RIMHE : Revue Interdisciplinaire Management, Homme(s) \& Entreprise, 2017. hal-02099443

HAL Id: hal-02099443

https://hal.science/hal-02099443

Submitted on 15 Apr 2019

HAL is a multi-disciplinary open access archive for the deposit and dissemination of scientific research documents, whether they are published or not. The documents may come from teaching and research institutions in France or abroad, or from public or private research centers.
L'archive ouverte pluridisciplinaire HAL, est destinée au dépôt et à la diffusion de documents scientifiques de niveau recherche, publiés ou non, émanant des établissements d'enseignement et de recherche français ou étrangers, des laboratoires publics ou privés. 
Research article

\section{SKILL-INDUCED MOBILIZATION AT WORK: A STUDY OF AN ACTIVIST GROUP}

Fabien Hildwein

ARIMHE | « RIMHE : Revue Interdisciplinaire Management, Homme \& Entreprise » 2017/2 n²6 | pages 49a à 72a

ISSN 2259-2490

Article disponible en ligne à l'adresse :

https://www.cairn.info/revue-rimhe-2017-2-page-49a.htm

Distribution électronique Cairn.info pour ARIMHE.

(C) ARIMHE. Tous droits réservés pour tous pays.

La reproduction ou représentation de cet article, notamment par photocopie, n'est autorisée que dans les limites des conditions générales d'utilisation du site ou, le cas échéant, des conditions générales de la licence souscrite par votre établissement. Toute autre reproduction ou représentation, en tout ou partie, sous quelque forme et de quelque manière que ce soit, est interdite sauf accord préalable et écrit de l'éditeur, en dehors des cas prévus par la législation en vigueur en France. Il est précisé que son stockage dans une base de données est également interdit. 
Research article

\title{
Skill-induced mobilization at work: a study of an activist group
}

Fabien HILDWEIN ${ }^{10}$

\begin{abstract}
This article explores the way in which skills may mobilize individuals within an organization. To that end, it considers skills rather as mobilizing resources for individuals than strategic resources for the firm. This suggests other ways through which skills can contribute to the firm and HR policies. The theoretical framework of resource mobilization, coming from the sociology of social movements, provides explanations in this regard. The empiric part is based upon a twelve-month ethnographic work among the feminist activist group "La Barbe". This part explores how an organization with few resources can mobilize and retain its members by providing skills that are coherent with their individual paths (especially the search for personal emancipation). Recommendations and the limits for human resources management are discussed to conclude, in particular, on the mobilization of talents.
\end{abstract}

\section{Keywords}

Skills, mobilization at work, social movements, activist group, ethnography.

10 Doctor in Management Sciences at HEC Paris, ATER LARGEPA (EA 3386) fabien.hildwein@gmail.com

Translation of: Mobilisation au travail par les compétences : les apports de l'étude des groupes activistes, RIMHE, Revue Interdisciplinaire Management, Homme \& Entreprise, n²6, printemps 2017, p.49-72. Translated by: Karine DEBBASCH.

This article was the subject of a communication in October 2016 at EM Strasbourg Business School for the $27^{\text {th }}$ congress of the AGRH (Human Resources Management Association) "Back to the future for HR Management."

RIMHE - Revue Interdisciplinaire Management, Homme \& Entreprise $\mathrm{n}^{\circ} 26$ - Printemps 2017 


\section{Skill-induced mobilization at work: a study of an activist group}

Fabien HILDWEIN

\section{Résumé}

Cet article explore la façon dont les compétences sont susceptibles de mobiliser les acteurs au sein d'une organisation. Pour ce faire, il considère les compétences non comme des ressources stratégiques au service de l'entreprise, mais comme des ressources facteurs de mobilisation au travail pour les individus. Le cadre théorique de la mobilisation des ressources, issu de la sociologie des mouvements sociaux, permet de saisir cette dimension des compétences. La partie empirique provient d'un travail ethnographique de 12 mois effectué auprès du groupe activiste féministe « La Barbe ». Elle explore comment une organisation disposant de peu de ressources peut mobiliser des individus en leur apportant des compétences cohérentes avec leurs parcours individuels et répondant à leurs attentes concernant notamment la recherche de l'émancipation personnelle. Les enseignements et les limites pour la mobilisation au travail par les compétences dans les organisations sont ensuite discutés pour conclure notamment sur les apports de l'étude pour la fidélisation des talents.

\section{Mots clés}

Compétences, mobilisation au travail, sociologie des mouvements sociaux, groupes activistes, démarche ethnographique. 


\section{Skill-induced mobilization at work: a study of an activist group \\ Fabien HILDWEIN}

\section{Introduction}

Managers consider skills as strategic resources serving the company, as individual or collective assets that directly contribute to global performance and that thus constitute tools of management. However, this approach may take into consideration only one dimension of skills, while it is a polysemous concept (Le Deist and Winterton, 2005) with numerous indirect effects on the performance and the strategy of a company (Chowhan, 2016).

The present article aims at exploring another contribution of skills to human resources management policies (HR Management) and to business projects, seeing them as a factor of mobilization among co-workers (Tremblay and Wils, 2005; Tremblay and Simard, 2005, Tremblay et al., 2005). Our objective is to shed light on how acquiring specific skills (through their rarity, or the employability gain they provide, or their consistency with a personal career, etc.) encourages individuals to stay in a given organization and to get involved in a collective project. Our approach is to "go from a logic of employment to an HR management based on the acknowledgement of each employee's capital of skills" (Retour, 2005, p. 187-188).

The research question at the heart of the present work thus bears on the way skills may be factors of mobilization at work in organizations, and on the characteristics of mobilizing skills for the individuals concerned. In this respect, the sociology of social movements provided us with a fertile theoretical framework to grasp the link between two phenomena that had so far remained distinct, namely that of the development of skills and that of mobilization at work. This line of research indeed focuses on the way individuals mobilize for one cause (feminism, antiracism, environmentalism, etc.) while receiving training and education to reach their goals. The empirical part explores the link between skills and mobilization by studying how activists from the feminist group "La Barbe" account for their personal commitment within this organization. The discussion then addresses the insight gained and the limits of the study. We conclude with what it brings to the mobilization of talents.

\section{Definition of the concepts and theoretical framework of the study}

In this section, we first present the definition of the concept of skills and of the notion of mobilization at work through skills. We then clarify the theoretical framework of the study, i.e. the sociology of social movements, so as to shed light on its relevance and to bring elements of response to our questions. 


\section{Skill-induced mobilization at work: a study of an activist group}

Fabien HILDWEIN

\subsection{The concept of skills}

Defining what skills are and how they may help organizations grow is vital to HR management (Retour, 2005). Despite numerous research articles on skills bases (Oiry and Sulzer, 2002; Labruffe, 2005), it remains a tedious task. Aubret and co-authors (2002) thus show that although definitions were provided, they often are the result of operative compromises between the various parties involved, notably companies, employees, trainers and researchers in management sciences or in work psychology. The hierarchical position (Green and James, 2003) as well as the nature of the organization (Grugulis, 2003) influence how individuals connect with the term "skills." Although there are diverse approaches to the concept of skills, due to the numerous topics that address them, and also to the managerial cultures in different geographical zones, they nonetheless tend to cover one and the same reality (Bouteiller and Gilbert, 2005; Gilbert, 2006).

In the present study, we essentially used Le Boterf's typology (2002), which is relatively easy to handle and is a good compromise between excessive generalization, which would make it ineffective, and too much precision, which would make it too complex to use. In addition, it meets the need for a holistic and multidimensional typology (Le Deist and Winterton, 2005), i.e. one that covers numerous aspects of skills, notably including the cognitive, operational and behavioral dimensions. This typology is based on the distinction between knowledge and know-how. Knowledge corresponds to the frameworks of analysis orienting action (theoretical knowledge) and to the knowledge a given individual has of the context within which he/she acts (environmental/contextual knowledge) as well as to his/her knowledge of the action modes and means he/she has at his/her disposal (procedural knowledge). As for knowhow, it corresponds to the capability of conducting an operation based on procedural knowledge (formalized know-how), to the tacit knowledge gained from experience (empirical know-how), to the capability of interacting within a social group (relational know-how) and/or to the capability of analyzing and solving problems (cognitive know-how). This typology is supplemented by the notion of social skills, accounting for the fact that certain skills do not only stem from knowledge, but also from one's relationship to oneself and to the world. These skills are different from relational know-how insofar as they not only entail an individual's relationship to others, but also his/her self-relationship (possibly to his/her own body), including for instance the confidence an individual may have in him/herself when confronted to a given situation.

One should nonetheless remember Le Boterf's repeated warning (2002) concerning this artificial division: "The skills of the professional consist in his/her using them adequately" (Le Boterf, 2002, p. 115). In other words, knowledge is a skill only when it is used appropriately in a given professional context. It thus cannot be separated from the individual who possesses and uses it. Furthermore, skill is not an addition of

RIMHE - Revue Interdisciplinaire Management, Homme \& Entreprise

$\mathrm{n}^{\circ} 26$ - Printemps 2017 


\section{Skill-induced mobilization at work: a study of an activist group \\ Fabien HILDWEIN}

resources, but a combination in which each element constitutes a part of the global system that must be considered as a whole. Knowledge, know-how and social skills therefore cannot be considered separately, but they only exist in the interaction of one with the others. This typology is thus mostly an analytical division meant to comprehend better the concept of skills, which has to be used cautiously.

\subsection{The mobilizing dimension of skills}

How do skills contribute to the project of the company? According to the resourcebased view of companies based on Penrose's (1963), Wenerfelt's (1984) as well as Prahalad and Hamel's (1990) research work, skills are considered as resources of human capital contributing to the performance of the company equally important as other types of resources (physical or organizational capitals). Indeed, on the one hand they increase the performance of each individual in the various work situations he/she encounters, and on the other hand they increase the collective performance of the company (Michaux, 2005; Dietrich et al., 2010). In this respect, one of the strategic challenges of HR management is to be able to anticipate the future needs of the company in terms of skills, and thus to constantly make the skills at the disposal of the company evolve so that they meet its strategic vision (Le Boulaire and Retour, 2008). It is also necessary to identify the rarest and most useful skills in order to create a competitive advantage. In addition to the difficulty of putting into practice a skillbased strategic HR policy (Defélix and Retour, 2008), this approach confines the HR manager, and HR in general, to a narrow role, taking into account only one of its dimensions, namely that of strategic partner, while neglecting others such as that of manager, employee champion or agent of change (Ulrich, 1996).

This criticism invites one to find other, skill-based modes of contributions to the project of the company. In this respect, it is necessary to review the destination of skills: they are resources, but for whom and to what aim? Skills serve individuals directly. They constitute resources for their career paths, and acquiring them is an important factor of motivation, encouraging employees' full mobilization to serve a business project. Several researchers presented skills as a factor of mobilization at work in organizations (Tremblay et al., 2005). Le Boterf underlined the interest of individuals for the "skills portfolio" a given company may offer employees as an incentive to hire (Le Boterf, 2015, p. 48). One of his suggestions, in order to rethink skills, is actually entitled "Positioning oneself as a skills provider and not merely as a job seeker" (Le Boterf, 2010, p.92). For Tremblay and Wils (2005, p. 38), mobilization in companies is defined as "a critical mass of employees accomplishing tasks (being part of their contract of employment or not, paid or unpaid) that favor the well-being of others, from their organization to the achievement of a common goal".

RIMHE - Revue Interdisciplinaire Management, Homme \& Entreprise $\mathrm{n}^{\circ} 26$ - Printemps 2017 


\section{Skill-induced mobilization at work: a study of an activist group \\ Fabien HILDWEIN}

This concept must be distinguished from other close concepts. As opposed to motivation, mobilization presupposes behaviors that go beyond the remits of one's position (Tremblay and Wils, 2005). It is also different from implication and from commitment, which are first and foremost psychological attitudes that predispose one to mobilization, but do not guarantee it (Bichon, 2005).

The way skills trigger individuals' mobilization remains unclear. To understand better the relationship between mobilization and skills, we chose to use a model from another field of research, namely the sociology of social movements.

\subsection{Theoretical framework of the sociology of social movements}

The central concept here is that of "social movement," defined as "Collectivities acting with some degree of organization and continuity outside of institutional or organizational channels for the purpose of challenging or defending extant authority, whether it is institutionally or culturally based, in the group, organization, society, culture, or world order of which they are part" (Snow et al., 2004, p. 11). A social movement comprises both individuals who often define themselves as "militants", and organizations whose main aim is to support one or several causes the movement supports. These organizations are called "social movement organizations" (SMOs). SMOs may be of different natures in accordance with the means they use to support their causes. They may for instance produce information, provide services to people needing help or exert media pressure to influence political leaders or business managers.

Mobilization of resources is one of the first theories in the sociology of social movements (Fillieule and Péchu, 1993). Its purpose is to account for collective action despite Olson's paradox (1965). Indeed, according to Olson, collective action is impossible if one considers individuals to be rational, insofar as although collective gains are important, individual gains are by far overstepped by the risks and the individual expenses entailed by moving into action. The most rational behavior is thus to play the role of the "free-rider," consisting in not acting to later enjoy the collective gains obtained by others. The authors of the theory of the mobilization of resources (Jenkins, 1985; McCarthy and Zald, 1973; McCarthy and Zald, 1977) develop the idea that SMOs enable collective action by accumulating the necessary resources. The actors embrace a SMO because it lowers the costs of action by giving them the means to act. The first resources to be taken into consideration were material and human, but other types of resources were then identified, such as the status of the SMO, the identity it confers to its members, the skills it allows them to acquire, the networks it puts them in contact with, as well as its organizational or institutional structures (Pierru, 2010). The theory of the mobilization of resources as is presented in the sociology of social movements explains why it is necessary to develop organizations

\section{RIMHE - Revue Interdisciplinaire Management, Homme \& Entreprise \\ $\mathrm{n}^{\circ} 26$ - Printemps 2017}




\section{Skill-induced mobilization at work: a study of an activist group Fabien HILDWEIN}

within social movements, as well as why individuals join them. It allows one to understand the role of organizations in mobilization.

More specifically, McCarthy and Zald (1973, 1977) adopt the so-called entrepreneurial approach of SMOs, considering they compete with one another to address the various causes defended by a social movement. They use the phrase "social movement industry." The more efficient a SMO is at defending a cause, the more legitimacy it gains and the more likely it is to gain resources. This model can all the better be said to be entrepreneurial as the authors explicitly state that this concept of social movement industry echoes that of "industry" in the economic acceptance of the term: "The definition of SMI (social movement industry) parallels the concept of industry in economics" (McCarthy and Zald, 1977, p.1279).

In our eyes, the theory of resource mobilization gives rise to a better understanding of the phenomenon of mobilization at work through skills. On the one hand, SMOs that compete to mobilize individuals for their causes may be compared with companies trying to attract the best candidates and to acquire a strong position, on the long-term, on the employment market. On the other hand, the definition of mobilization is close to that presented in the sociology of social movements. The idea that mobilization is a collective phenomenon, both at the scale of the individual and beyond him/her, requiring a critical mass of individuals to occur, is very similar to the interest for collective action presented in the sociology of social movements (Fillieule and Péchu, 1993). Similarly, considering that the mobilized individuals "perform actions that are beneficial to the well-being of others, to their organization and to the accomplishment of a collective work" (Tremblay and Wils, 2005, p. 38) does correspond to mobilization within SMOs.

Although this definition somewhat combines management sciences and the sociology of social movements, the approach of these two disciplines has so far been quite different. Generally, the sociology of social movements tends to either consider mobilization on a very large scale, be it across time (Koopmans, 2004; Tarrow, 1983) or space (Sommier, 2010; Tarrow, 2005; Tarrow and della Porta, 2005), or to favor a psychological approach based on a commitment offer (Klandermans, 2004) or on analysis frameworks (Snow and Benford, 1988; Snow et al., 1986). Management sciences, on the contrary, look for factors of mobilization within organizations, be it a positive climate based on the recognition of individual efforts (Tremblay and Simard, 2005), or more concrete management practices (Tremblay et al., 2005). In addition, the effects of mobilization on the financial profitability of companies have remained one of the managers' major preoccupations (Ait Razouk and Bayad, 2011; BarraudDidier et al., 2003), which is not the case in the sociology of social movements. 


\section{Skill-induced mobilization at work: a study of an activist group}

Fabien HILDWEIN

The research question at the origin of our study is that of the contributions the study of a social movement via the prism of resource mobilization in sociology might bring to the understanding of the phenomenon of skill-based mobilization at work in organizations.

\section{Methodology of the empirical study}

In order to shed light on skills as mobilizing resources for individuals, we focused on the study of activist groups, which represent a specific category of SMO concentrating upon operations meant to draw attention to causes that underline their importance and give them legitimacy. These often are small organizations with limited structure and few resources. Their members are called activists. So that they might be seen and heard, activist groups resort to "performances" in which they visually express their message and their support for their cause. Rallies are the most common performances, but there are numerous others, such as picket lines, petitions, actions on social networks, happenings, etc. This term is borrowed from the world of the theatre and refers to the plays a company masters and uses for each performance. They have no financial resources and rely on volunteers. Mobilization factors are thus other than compensation, while those collectives incidentally enjoy a very high level of mobilization from their members. Activist groups are therefore particularly relevant for our study.

\subsection{The field of study: La Barbe, a feminist action group}

We chose to study La Barbe, a group of activists exposing the absence of women in positions of power, be it actual power (management positions, representation among the candidates from a party or among the elected representatives) or symbolical power (representation among experts and speakers during a conference or in a think tank). The group is made of thirty or so strongly involved women activists, as well as a hundred sympathizers who occasionally take part in the performances. In terms of ages, they span fairly uniformly between 25 and 65 , although the founders are older women, who have already had an important militant and feminist career. As far as their occupations are concerned, they mostly have higher intellectual professions independent consultants, artists, journalists, producers, photographers, researchers, primary school teachers - but they seldom work in a company. The youngest ones pursue higher education. La Barbe voluntarily has a very weak organizational structure (refusal of any hierarchy, almost no bureaucracy, fast decision processes). The main performance of La Barbe always follows the same protocol. The activists identify an organization (political, economical, cultural, humanitarian or religious) in which the positions of power are mainly occupied by men. When the organization takes part in a public event, notably general assemblies and press conferences, the activists go to the event and melt into the crowd. Once the event has started, the 


\section{Skill-induced mobilization at work: a study of an activist group \\ Fabien HILDWEIN}

activists place fake beards on their faces and climb onto the platform next to the speakers or gather in front of the stage. They keep quiet, calm, with their arms crossed. Two of them display a banner. One of the activists then takes the floor or speaks in a microphone. She reads a pre-written document, in which the activists ironically congratulate the organization for their success at keeping women away from places of power. Then the activists shake hands with the speakers and quickly leave. The document is handed out to the public, and photos of the action as well as the document are sent to a list of journalists and posted on social networks (Facebook and Twitter). In itself, the nature of the performance bears witnesses to the activist's strong mobilization to confront the situation and bring it to a successful conclusion.

\subsection{Collection and analysis of the data}

This empirical section is based on a 12-month ethnographic-type survey conducted between July 2011 and July 2012 among the group. It consisted of participant observation and interviews with the main actors, and also involved the collection of all available documents. The ethnographical study was also characterized by the researcher's immersion into the life of the group.

The whole data collected are comprised of: 38 interviews of La Barbe members, of journalists who had written articles on La Barbe or of diversity managers of the companies concerned by La Barbe actions; observation notes on 18 La Barbe actions and 25 internal meetings; 2325 pictures of La Barbe actions; 226 press articles on $L a$ Barbe found on Factiva and LexisNexis (see Annex 2); 93 press releases La Barbe emitted; and 138 La Barbe leaflets.

The three corpora of text (interviews, press articles and leaflets) were analyzed by coding with content analysis software (NVivo), which made it possible to define the main themes they address. The data used in the present article come from the interviews conducted with $18 \mathrm{La}$ Barbe activists, as well as from the observations made during the actions. The interviews use the life history method (Bertaux, 1997; Sanséau, 2005) so as to capture the militant and/or feminist history of La Barbe activists, to understand the phases they go through, the choices they make, the part of chance (fortuitous encounters, unexpected discoveries) and the meaning they give, $a$ posteriori, to their commitment. A second series of questions are added to these in order to capture their point of view on the performances they participate in, as well as the meaning they give to the various elements constituting them. We used an interview guide (Annex 1). In accordance with the semi-directive interview techniques used in ethnography, the interviewees are given a lot of time to respond, and the interviewer encourages them to continue the thread of their thoughts without influencing them so as to bring out issues and themes that the interview guide might not initially cover. Having lived within the group and shared their experiences allows the ethnographer to understand fully the interviewees' message. The approach is interpretative. It aims at 


\section{Skill-induced mobilization at work: a study of an activist group Fabien HILDWEIN}

understanding the explanations that the individuals give concerning their activity and, aligning them with our observations, at describing the events and the subjectivity of the individuals living them and making them happen (Beaud and Weber, 2010).

Coding the activists' interviews first allowed us to identify the sense units, and then to group them in larger categories shedding light on the major themes tackled by the activists: Meaning given to the performances, Relation to the medium, Mobilization factors and Internal functioning of the group. The theme "Mobilization factors" falls into the following categories: Affects (affects caused by the action, management of the affects by the organization), Acquired skills (developed in this work), Militant career (commitment in other social movements, personal and professional evolution) and Feminist career (intimate evolution of the person, both intellectually and in terms of activist engagement). The categories "Militant career" and "Feminist career" were no surprise, but those of "Affects," "Acquired skills," "Relation to the medium" and "Internal functioning" surfaced during the survey. Although this approach is similar to that of grounded theory (Corbin and Strauss, 1990; Glaser and Strauss, 1967), we took into consideration the warning not to group unquestioningly all the qualitative methodologies under this term (Suddaby, 2009). Thus, the present work was built by iterative back and forth considerations of the theory and of the results from fieldwork, the concepts shedding light onto the ethnographic experience, and the latter in turn permitting to discuss the theories (Beaud and Weber, 2010) - and not by going from the fieldwork to the concepts, as in grounded theory.

In the present research work, the ethnographic method gives access to the inner experience of the activists, notably their emotions, the evolution of the analysis frameworks and the skills they acquire during action, which all pertain to the activists' mobilization. The immersion of the researcher into a given social context allows to fully bring out the meaning of the actions, interactions and speeches of the actors (Rouleau et al., 2014) and, in an exploratory perspective, to understand relations that have so far been little studied and are difficult to grasp, such as those between skill acquisition and mobilization. Ethnography seems all the more appropriate to address the notion of skills as the latter cannot be separated from their context, and also due to the way the actors' own professional activity makes sense to them (Capaldo et al., 2006). This work thus takes part of the "ethnographic turning point" initiated some ten years ago by the study of organizations and of management (Cunliffe, 2010; Watson, 2011) that triggered today's renewal of the ethnographic methods (Rouleau et al., 2014). 


\section{Skill-induced mobilization at work: a study of an activist group \\ Fabien HILDWEIN}

\section{Results: the development of the activists' skills}

From the very start of the research work, the interviews unexpectedly shed light on the importance of skills in the activists' mobilization. More precisely, two elements play a role: the content of the skills themselves, which are perceived as emancipatory by the activists and thus correspond to the reasons that made them join the group; and the modes of acquisition of these skills among the activist group, which are closely linked to the content of these skills and are inseparable from participation to the group.

\subsection{Activists' acquisition of skills}

Being part of La Barbe gives rise to the long-term acquisition of two types of skills. First of all, participating to the life and actions of La Barbe allows one to develop a militant and feminist awareness, i.e. to acquire new analytical frameworks allowing one to interpret reality in each given situation (Goffman, 1974). It consists in theoretical knowledge, orienting action and giving it meaning. The activists describe their own evolutions and their gradual adherence to feminism in the following words:

"Being part of La Barbe encourages us to document our calls for actions and to change our views. At one time, it is about changing your own perspective. I am on the bus, I am at a meeting, I am at a family meal, what is at play, how many men are there, how many women are there, who takes the floor, who occupies the space, who takes decisions - things I was absolutely unaware of. I thought we were equal and that was it. You progressively pay more attention to what is going on in actual facts rather than to what you feel. You realize that all the aspects of public life are governed by men. This is exactly the feeling - that you have put on a pair of glasses." [Aline and Coraline - September 21, 2011]

More precisely, this change of perspective comes back to consciously adopting a feminist analysis framework, one that replaces former frameworks the individuals were less aware of. This unveiling represents an inner turning point for activists, for whom situations that were so far considered as natural and taken for granted are suddenly perceived as problematic, and thus as requiring them to take action. Along with this evolution, activists often mention their discovery of feminist authors and theoretical frameworks, mainly belonging to materialist feminism (Delphy, 1979) and queer feminism (Butler, 1990). But the development of a militant awareness is not confined to the acquisition of new frameworks or theoretical elements, it has to be understood as an intellectual evolution in every sense:

Researcher: "You told me you were taking your first steps in feminism - what did you mean?"

Amelia: "I didn't know how to be an activist, I didn't know what to think, my thought process was not clear, I felt there was something wrong but I was unable to sort things out. You look closer, and you feel that there is a problem. You feel

RIMHE - Revue Interdisciplinaire Management, Homme \& Entreprise

$\mathrm{n}^{\circ} 26$ - Printemps 2017 


\section{Skill-induced mobilization at work: a study of an activist group}

Fabien HILDWEIN

there's a connection, even if it's not very clear yet. That's why I talked about first steps, I knew nothing about the history of feminism, or about the major figures of feminism either." [Amelia - March 20, 2013]

The process does not merely consist in accumulating knowledge. It is a thoughtclarification work, allowing one to go from a state where intuition and search for coherence prevail, to a clear expression of ones' ideas and an explicit adherence to feminism. The effort of "putting one's ideas in order" allows one to assert one's convictions. This cognitive know-how allows one to solve various questions with new tools and new approaches.

Militant and feminist awareness is not all, and the evolution of activists goes beyond the intellectual level of analysis and interpretation of the world. It also affects their relation to the public space.

"The use of space - I now pay more attention if I am on the metro, I am a woman so I have a right to be there too, I'm not gonna curl up as I used to. So when I walk, I tell myself, if some guy or even a woman walks towards me, I'm not gonna step back, a habit I once had: "excuse me for existing, sorry, sorry." Now I know that when I sit down on the metro, I have the right, and I have the right to jostle others if I consider they take much more space than they should." [Amelia - March 20, 2013]

The idea is learning how to claim space for oneself and how not to justify one's presence. This importance of the body (feeling legitimate to act and to be present in a place of power), of the relation to oneself (notably by questioning one's primary socialization) and of the relation to others (in front of an authority deemed illegitimate) justify using the specific phrase of "social skills" rather than that of relational knowhow, which only concerns the relationship to others, or empirical know-how, which only concerns the relationship to things.

The development of political awareness and the development of social skills are truly emancipating processes. First of all, feminist awareness entitles one to consider oneself as a fully legitimate political subject:

"Becoming a militant for this cause opened the field of politics for me as something in which I could intervene. Whereas before, being a girl, and this is really a girl's elaboration, I didn't even dare to think, I didn't even think I could have ideas on politics, I used to let the others think for me. I listened to them, I chose ideas from the panel of other people's ideas, but I didn't dare positioning myself, I positioned myself in accordance with other people's choices, as if I was picking fruits from the store. And at one point I thought, being a feminist is doing politics". [Anne-Louise - February 2, 2012] 


\section{Skill-induced mobilization at work: a study of an activist group \\ Fabien HILDWEIN}

Again, emancipation is not merely an intellectual phenomenon, it is also another way of considering oneself, involving accepting one's ambition and considering oneself worthy of exerting one's power, just like men:

"La Barbe taught me something, and that is to assume my ambitions. For me, ambition had always been connoted as something wrong, but in fact it's connoted as wrong only for women. An ambitious guy is all right. But an ambitious woman yuck! And then, I believe there is something there too, when we invite ourselves in these places of power, we don't expect you to take us by the hand and allow us to access these places of power, we just burst in, and whether you like it or not we're there." [Justine - January 20, 2012]

For the older activists, this change is deeply rooted in their personality, it affects their whole lives and questions their relation to conflict and to authority, and thus it goes much beyond the initial limits of the project. A founder thus said:

"It represents something more personal, more individual, attested by many members of La Barbe. It is true empowerment. I believe people don't realize how difficult it is to do this, the simple act of putting on a beard, climbing up on a platform, in front of a hostile assembly. When you are a woman and you've been taught not to raise your voice, to be a good pupil, to be an accomplished woman or wife who does not voice her opinion too much, the world has not raised us to fight for ourseves. It's very complicated for us, women, to establish ourselves. For me it also has a personal meaning, and I know that every bearded woman who climbs on the platform does it for La Barbe and to convey a message that goes beyond them, but it also transforms them and it has a hold on them and it also gives them the courage to open their mouths when some macho at their job says something that infuriates them, it gives them the courage to do lots of things, so it's a true emancipation training. An action at La Barbe is much richer than it may seem from the outside and it never leaves anyone unscathed". [Anique - February 26, 2013]

Joining $\mathrm{La}$ Barbe entails freeing oneself from a feminine education and socialization perceived as constraining. The unveiling concerns both social situations and one's own self. These experiences thus contribute to the emancipation of the activists through the acquisition of skills within La Barbe. These skills are not acquired merely to act better within the organization, but also for oneself. Feminist action at La Barbe affects both its targets and its members. The emancipatory nature of these skills is inseparable from the project of the activist group, which accounts for the activists' attachment to the group and thus constitutes a central pillar of mobilization. 


\section{Skill-induced mobilization at work: a study of an activist group}

Fabien HILDWEIN

\subsection{The mobilizing development of skills}

Although the emancipatory nature of the skills acquired at La Barbe accounts for their mobilizing force, it is not the only reason. Indeed, it is through participating to actions, being part of the community and through recruitment that activists acquire and maintain these skills. In addition, the skills themselves reinforce each other and favor their acquisition.

Participating to actions at $L a$ Barbe allows the activists to develop their selfconfidence, to feel easier with an authority, and to rethink their relationship to space.

"When it comes to climbing on the platform I have to force myself a little, and that's also something for which I am grateful to La Barbe because it forced me to go beyond myself; twenty times my heart was pounding hard in my chest but now I have no doubt whatsoever concerning the legitimacy of our action". [Louise - January 25, 2012]

There is a strong link between action and personal evolution: the act of defying authority and to impose themselves in places of power changes the activists. Doing this, they prove to themselves that they can confront authority and take on the hostility their action triggers. Action allows them to explore very concretely personal capabilities they had not previously considered or truly experimented. They gain more self-confidence and develop courage to face up to authority figures. In addition, imposing themselves both symbolically and physically in places of power helps the activists to also do so in their daily lives, and to re-conquer public space. More broadly speaking, the change of framework and the cause chosen by La Barbe are linked: by intervening next to power and by exerting their critical thinking, the activists allow themselves to consider themselves as political subjects.

The second mode of acquisition of skills is situated at the level of the internal life of the group, through the meetings that take place before and after actions, and the debates on electronic worklists. First of all, this mode facilitates the change of frameworks and the transmission of feminist concepts and theories, as the activists recommend books to each other and talk about it. But it also encourages internal speaking, which contributes to develop the activists' relational skills (debating and public speaking):

"It is a collective where there are many major personalities. One must impose oneself, impose one's personality, in front of people who write very well, whose thinking is elaborated. We manage to say that we do not agree with this or that. I was unable to do this before and now I feel that in the professional environment, I see the evolution that I've had, in meetings I take it much easier to speak, I share my opinions and can assert things, and I say, "this is strange, there are no women," on 


\section{Skill-induced mobilization at work: a study of an activist group \\ Fabien HILDWEIN}

this topic but also about things that bother me and that I disagree with." [Amelia March 20, 2013]

The activist group also constitutes a speaking space where the activists get used to public speaking. Internal debating at La Barbe occurs during non-mixed meetings, precisely in order to allow women to express themselves freely. These debates are sometimes heated, which is all the better practice for the activists. Finally, welcoming and integrating new activists also gives them opportunities to acquire skills. La Barbe aims at integrating newcomers as fast as possible, by pushing them to take responsibilities as early as possible - for instance, coordinating an action or a meeting, or speaking to journalists on behalf of the group, etc. The general idea is to establish and maintain a particular climate that encourages activists to gain autonomy and independence.

"Even if you've only been at La Barbe for two hours you have the right to express yourself and to give an interview, of course when I say two hours I'm exaggerating a little, but the spirit is really that "we have no monopoly on knowledge," we share and we're a collective and it's the idea of empowerment, it's "go for it because you'll learn how to do it precisely by doing it". [Amelia - 20 mars 2013]

The activist phrases one of the explicit principles of the group: "you'll learn how to do it precisely by doing it", which means that if an activist wants something or suggests something, she is encouraged to make it happen by herself. Rather than relying on other people's skills, she must develop her own skills through practice, "on the job." It is also a feminist issue: the emancipation of women goes through the acquisition of skills allowing a greater social autonomy, notably towards men. The activists often describe the fact of thus taking responsibility as an "intoxicating" experience. $L a$ Barbe therefore acts as a laboratory where the activists may train to exercise responsibilities, relatively limited as they might be, and similarly their internal debating makes it easier for them to speak in public. Skills mutually reinforce each other, in so far as mastering certain skills makes it easier to acquire other skills. They cannot be considered individually or taken out of their context. The change of frameworks is largely facilitated by the acquisition of theoretical knowledge on feminism, which sheds a different light on social situations. The theoretical elements also make it easier to move into action, giving good reasons to risk it, the point being to break the social codes and to expose oneself during a rally:

"So of course the people watching us do not see the theoretical background. It is all very intellectual, very theoretical. When you are on the platform, if you question the audience, nobody will have that degree of analysis. But we know why we do it, we are aware and embrace our motivation, it feels good to us. " [Anique - February 26, 2013] 


\section{Skill-induced mobilization at work: a study of an activist group Fabien HILDWEIN}

Conversely, theoretical knowledge is all the better used due to the relational skills developed during internal debates, through which the activists explore the feminist theories and arguments.

Table 1: Synthesis of the skills acquired at La Barbe

\begin{tabular}{|c|c|c|c|c|}
\hline & Acquired skills & Type of skill & Mode of acquisition & Facilitators \\
\hline \multirow{3}{*}{ 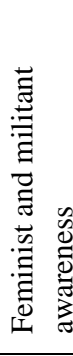 } & $\begin{array}{l}\text { Feminist theories } \\
\text { and concepts }\end{array}$ & $\begin{array}{l}\text { Theoretical } \\
\text { knowledge }\end{array}$ & $\begin{array}{l}\text { Internal life of the } \\
\text { group; individual } \\
\text { reading }\end{array}$ & $\begin{array}{l}\text { Internal debates / } \\
\text { debating }\end{array}$ \\
\hline & $\begin{array}{l}\text { Feminist analysis } \\
\text { frameworks }\end{array}$ & $\begin{array}{l}\text { Cognitive know- } \\
\text { how }\end{array}$ & $\begin{array}{l}\text { Internal life of the } \\
\text { group }\end{array}$ & $\begin{array}{l}\text { Feminist theories } \\
\text { and concepts }\end{array}$ \\
\hline & $\begin{array}{l}\text { Seeing oneself as a } \\
\text { political subject } \\
\text { and assuming one's } \\
\text { ambitions }\end{array}$ & $\begin{array}{l}\text { Relational know- } \\
\text { how }\end{array}$ & $\begin{array}{l}\text { General } \\
\text { participation to the } \\
\text { group }\end{array}$ & $\begin{array}{l}\text { Feminist analysis } \\
\text { frameworks }\end{array}$ \\
\hline \multirow{4}{*}{ 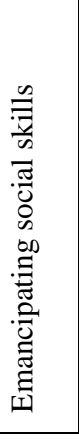 } & $\begin{array}{l}\text { Self-trust and trust } \\
\text { in authority }\end{array}$ & Social skills & $\begin{array}{l}\text { Imposing oneself } \\
\text { physically during } \\
\text { actions }\end{array}$ & $\begin{array}{l}\text { Participation to } \\
\text { actions }\end{array}$ \\
\hline & $\begin{array}{l}\text { New relation to the } \\
\text { public space }\end{array}$ & Social skills & $\begin{array}{l}\text { Imposing oneself } \\
\text { physically during } \\
\text { actions }\end{array}$ & $\begin{array}{l}\text { Participation to } \\
\text { actions }\end{array}$ \\
\hline & Debating in public & $\begin{array}{l}\text { Relational know- } \\
\text { how }\end{array}$ & $\begin{array}{l}\text { Internal life of the } \\
\text { group }\end{array}$ & $\begin{array}{l}\text { Protected single-sex } \\
\text { spaces }\end{array}$ \\
\hline & Autonomy & Social skills & $\begin{array}{l}\text { Welcoming } \\
\text { newcomers }\end{array}$ & $\begin{array}{l}\text { Developing self- } \\
\text { trust and trust in } \\
\text { others }\end{array}$ \\
\hline
\end{tabular}

\section{Discussion: skills as a lever of mobilization}

Thus, skills may be mobilization factors when they take part in a personal development and when the individuals consider them as useful resources, both for their personal development and for the organization. Mobilization through skills works all the better as the latter's acquisition is rooted in the very activity of the organization, and more generally in the integration and the socialization of the individuals within the group.

The results of the present study thus enrich the link between employee retention and skills. Several research works insist on the importance of keeping skills by retaining employees, notably high-potential ones (Dejoux and Thévenet, 2015), and more particularly in times of crisis (Giraud, Roger and Thomines, 2012). It has to be observed too that retention will also go through training the individuals and giving

RIMHE - Revue Interdisciplinaire Management, Homme \& Entreprise $\mathrm{n}^{\circ} 26$ - Printemps 2017 


\section{Skill-induced mobilization at work: a study of an activist group Fabien HILDWEIN}

them the opportunity to develop within the company. The present research work thus suggests a virtuous circle between skills and retention: the individuals join, remain and mobilize within an organization for the skills it confers them, and they reinforce their skills by thus contributing to the organization. To this aim, offering a panel of rare skills, i.e. skills that cannot be acquired within other organizations, represents a competitive advantage on the employment market to both recruit and retain talented employees. The skills that correspond to a personal need and to an individual career are particularly valuable in this respect, more especially concerning questions of emancipation and personal development.

In the case we studied, the commitment of the activists is not made exclusively for a given cause, but it also corresponds to a personal desire of evolution that closely intermingles with their attachment to this cause. Similarly, skills serve both the individuals and the group. They are acquired by an individual effort and by participating to the general life of the group. More generally, mobilization through skills defines the way individuals appropriate and share resources to make collective action possible, and the organization exists because it provides each individual with the means to mobilize. Thus, skills connect individuals to the collective, allowing them to act for the organization, and at the same time attaching them to the organization. This relation invites one to go beyond the questions opposing individual and collective objectives, as in Olson's paradox (1965): dynamics such as those of the appropriation of resources and the acquisition of skills influence both and bring them together.

The most obvious limit of the present work lies in the differences between activist groups and larger, more structured organizations or, more generally speaking, companies. The first difference refers to the nature of the individuals. Activists and company employees are comparable insofar as they are organization members having a specific type of career, but they fundamentally differ in their relation to their organization and to their activity. Activists share affects (notably indignation) and frameworks of analysis that facilitate their coordination and their mobilization around a common project, whereas most employees are less prone to collective action and to having a passionate relation to their activity. In addition, employees are contractually bound, and they commit to a company in exchange for a salary, whereas activists are much more volatile, and can change organizations (or even give up militancy) without any costs for them; staying within the organization depends only on their goodwill. Finally, activists' joining a group presupposes their prior mobilization, at least at the beginning. The first challenge for the activist group thus consists in maintaining the existing mobilization and to retain its members, whereas the challenge for the company rather consists in arousing this mobilization among people whose relation to employment is also based on necessity, not merely on vocation. The second difference refers to the nature of the skills considered. Activists tend to favor skills that correspond to their cause - emancipation for feminism; expertise in subjects pertaining 


\section{Skill-induced mobilization at work: a study of an activist group}

Fabien HILDWEIN

to the sciences of nature (biology, systems theory, climatology, nuclear physics, etc.) for environmentalism; legal and organizational skills to mount a demonstration, etc. Company employees may also be affected by this dimension as political subjects, they may even request the defense of professional equality or the environment be taken into account, but their tendency, due to the necessities of employment, is to develop skills that may be transferred to other positions and that are likely to strengthen their employability and their career progression.

\section{Conclusion}

Studying the mobilization of activists through skills opens the reflection on good management practices in companies. La Barbe activists discovered themselves and asserted their opinions through their actions within this group. They acquired a kind of professionalism, implemented audacious skills, developed new ones and favored their personal development. Transposition to the company invites futures research. It sheds light on the importance of the meaning attributed by organizational actors to their commitment at work, as well as on ongoing learning and emancipation through work, which are potentially involved in joining an organization. It invites one to consider people's resources as talents whose development management should support, an approach that might be supported by skill-related mobilization at work.

\section{Bibliographical references}

Aït Razouk A., Bayad M. (2011), GRH mobilisatrice et performance des PME, Revue de Gestion des Ressources Humaines, vol.82, n 4, p. 3-18.

Aubret J., Gilbert P., Pigeyre F. (2002), Management des compétences : réalisations concepts analyses, Paris, Dunod.

Barraud-Didier V., Guerrero S., Igalens J. (2003), L'effet des pratiques de GRH sur la performance des entreprises : le cas des pratiques de mobilisation, Revue de Gestion des Ressources Humaines, vol.47, p. 2-13.

Beaud S., Weber F. (2010), Guide de l'enquête de terrain, Paris, La Découverte.

Bertaux D. (1997), Le récit de vie, Paris, Armand Colin.

Bichon A. (2005), Comment appréhender les comportements de mobilisation collective des salariés, Gestion, vol.30, n², p. 50-59.

Bouteiller D., Gilbert P. (2005), Réflexions croisées sur la gestion des compétences en France et en Amérique du Nord, Relations industrielles/Industrial Relations, vol.60, $\mathrm{n}^{\circ} 1$, p. 3-28.

Butler J. (1990), Gender Trouble: Feminism and the Subversion of Identity, New York, Routledge.

Capaldo G., Iandoli L., Zollo G. (2006), A situationalist perspective to competency management, Human Resource Management, vol.48 n³, p. 429-448. 


\section{Skill-induced mobilization at work: a study of an activist group \\ Fabien HILDWEIN}

Chowhan J. (2016), Unpacking the black box: understanding the relationship between strategy, HRM practices, innovation and organizational performance, Human Resource Management Journal, vol.26, n², p.112-133.

Corbin J. M., Strauss A. L. (1990), Grounded theory research: Procedures, canons, and evaluative criteria, Qualitative Sociology, vol.13, $\mathrm{n}^{\circ} 1$, p. 3-21.

Cunliffe A. L. (2010), Retelling Tales of the Field, Organizational Research Methods, vol.13, n², p. 224-239.

Defélix C., Retour D. (2008), Peut-on relier stratégie d'entreprise et gestion des compétences ?, in Dupuich-Rabasse F., Management et gestion des compétences, Paris, L'Harmattan, p. 199-216.

Dejoux C., Thévenet M. (2010), La gestion des talents, La GRH d'après-crise, Paris, Dunod.

Delphy C. (1979), L'ennemi principal, 1 Economie politique du patriarcat, Paris, Editions Syllepse.

Dietrich A., Gilbert P., Pigeyre F., Aubret J. (2010), Management des compétences : enjeux, modèles et perspectives, Paris, Dunod.

Fillieule O., Péchu C. (1993), Lutter ensemble, Les théories de l'action collective, Paris, L'Harmattan.

Gilbert P. (2006), La compétence : concept nomade, significations fixes, Psychologie du Travail et des Organisations, vol.12, p. 67-77.

Giraud L., Roger A., Thomines S. (2012), La fidélisation des ressources humaines en période de crise économique, Revue de Gestion des Ressources Humaines, vol.84, p.44-76.

Glaser B. G., Strauss A. L. (1967), The discovery of grounded theory: Strategies for qualitative research, New York, Aldine.

Goffman E. (1974), Frame Analysis, An essay on the organization of experience, Chicago, Northeastern University Press.

Green F., James D. (2003), Assessing skills and autonomy: the job holder versus the line manager, Human Resource Management Journal, vol.13, n 1, p.63-77.

Grugulis I. (2003), Putting skills to work: learning and employment at the start of the century, Human Resource Management Journal, vol.13, n², p.3-12.

Jenkins J. C. (1985), The Policy of Insurgency, New York, Columbia University Press. Klandermans B. (2004), The Demand and Supply of Participation: SocialPsychological Correlates of Participation in Social Movements, in Snow D. A., Soule S. A., Kriesi H., Eds, The Blackwell Companion to Social Movements, Oxford, Blackwell Publishing, p. 360-379.

Koopmans R. (2004), Protest in Time and Space: The Evolution of Waves of Contention, in Snow D. A., Soule S. A., Kriesi H., The Blackwell Companion to Social Movements, Oxford, Blackwell Publishing. 


\section{Skill-induced mobilization at work: a study of an activist group}

Fabien HILDWEIN

Labruffe A. (2005), Management des compétences, construire votre référentiel, La Plaine Saint Denis, AFNOR éditions.

Le Boterf G. (1994), De la compétence: Essai sur un attracteur étrange, Paris, Les Editions d'Organisation.

Le Boterf G. (2002), Développer les compétences des professionnels, Paris, Editions d'Organisation.

Le Boterf G. (2010), Repenser la compétence : Pour dépasser les idées reçues : quinze propositions, Paris, Eyrolles.

Le Boterf G. (2015), Construire les compétences individuelles et collectives: Agir et réussir avec compétence, les réponses à 100 questions, Paris, Eyrolles.

Le Boulaire M., Retour D. (2008), Gestion des compétences, stratégie et performance de l'entreprise : quel est le rôle de la fonction RH ?, Revue de Gestion des Ressources Humaines, vol.70, p. 51-68.

Le Deist F.D., Winterton J. (2005), What is competence?, Human Resource Developement International, vol.8, ${ }^{\circ} 1$, p. 27-46.

McCarthy J. D., Zald M. N. (1973), The Trend of Social Movements in America: Professionalization and Resource Mobilization, Morristown, NJ, General Learning.

McCarthy J. D., Zald M. N. (1977), Resource Mobilization and Social Movements: A Partial Theory, American Journal of Sociology, vol.82, nº, p. 1212-1241.

Michaux V. (2005), Compétences collectives et haute performance: apports théoriques et enjeux organisationnels, Revue de Gestion des Ressources Humaines, vol.58, p.45-74.

Moore S., Read I. (2006), Collective organization in small- and medium-sized enterprises - an application of mobilization theory, Human Resource Management Journal, vol.16, nº 4, p.357-375.

Oiry E., Sulzer E. (2002), Les référentiels de compétences : enjeux et formes, in Brochier D., La Gestion des Compétences. Acteurs et Pratiques, Paris, Economica, p.29-47.

Olson M. Jr. (1965), The Logic of Collective Action: Public Goods and the Theory of Groups, Cambridge, Harvard University Press.

Prahalad C.K., Hamel G. (1990), The core competence of the corporation, Harvard Business Review, vol.68, n³, p. 63-76.

Penrose E. (1963), Facteurs, conditions et mécanismes de la croissance d'une entreprise, Paris, Hommes et Techniques.

Pierru E. (2010), Organisations et Ressources, in Fillieule O., Agrikoliansky E., Sommier I., Penser les mouvements sociaux, Paris, La Découverte, p.19-38.

Retour D. (2005), Le DRH de demain face au dossier compétences, Management et Avenir, vol.2, n 4 , p. 187-200.

RIMHE - Revue Interdisciplinaire Management, Homme \& Entreprise

$\mathrm{n}^{\circ} 26$ - Printemps 2017

-68 - 


\section{Skill-induced mobilization at work: a study of an activist group \\ Fabien HILDWEIN}

Rouleau L., de Rond M., Musca G. (2014), From the ethnographic turn to new forms or organizational ethnography, Journal of Organizational Ethnography, vol.3, ${ }^{\circ} 1$, p.2-9.

Sanséau P.-Y. (2005), Les récits de vie comme stratégie d'accès au réel en sciences de gestion: pertinence, positionnement et perspectives d'analyse, Recherches Qualitatives, vol.25, $\mathrm{n}^{\circ} 2$, p. 33-57.

Snow D. A., Benford R. D. (1988), Ideology, Frame Resonance, and Participant Mobilization, International Social Movement Research, vol.1, p. 197-217.

Snow D. A., Rochford E. B., Worden S. K., Benford R. D. (1986), Frame Alignment Processes, Micromobilization, and Movement Participation, American Sociological Review, vol.51, n4, p. 464-481.

Snow D. A., Soule S. A., Kriesi H. (2004), Mapping the Terrain, in Snow D. A., Soule S. A., Kriesi H., The Blackwell Companion to Social Movements, Oxford, Blackwell Publishing, p. 3-16.

Sommier I. (2010), Diffusion et circulation des mouvements sociaux, in Fillieule O., Agrikoliansky E., Sommier I., Penser les mouvements sociaux, Paris, La Découverte, p.101-120.

Suddaby R. (2009), From the editors: What grounded theory is not, Academy of Management Journal, vol.49, n 4, p. 633-642.

Tarrow S. (1983), Struggling to reform: Social Movements and Policy Change during Cycles of Protest, Ithaca, N.Y., Western Societies Program, Cornell University.

Tarrow S. (2005), New Transnational Activism, Cambridge, Cambridge University Press.

Tarrow S., della Porta D., Dir. (2005), Transnational Protest and Global Activism, Lanham, Rowman et Littlefield.

Tremblay M., Chênevert D., Simard G., Lapalme M.-E., Doucet O. (2005), Agir sur les leviers organisationnels pour mobiliser le personnel : le rôle de la vision, du leadership, des pratiques de GRH et de l'organisation du travail, Gestion, vol.30, n², p. 69-78.

Tremblay M., Simard G. (2005), La mobilisation du personnel : l'art d'établir un climat d'échanges favorable basé sur la réciprocité, Gestion, vol.30, n², p. 60-68.

Tremblay M., Wils T. (2005), La mobilisation des ressources humaines : une stratégie de rassemblement des énergies de chacun pour le bien de tous, Gestion, vol.30, n ${ }^{\circ} 2$, p.37-49.

Ulrich D. (1996), Human Resource Champions. The next agenda for adding value and delivering results, Boston, Harvard Business School Press.

Watson T. J. (2011), Ethnography, Reality, and Truth: The Vital Need for Studies of "How Things Work" in Organizations and Management, Journal of Management Studies, vol.48, n 1 , p. 202-217. 
Skill-induced mobilization at work: a study of an activist group

Fabien HILDWEIN

Wenerfelt B. (1984), A resource-based view of the firm, Strategic Management Journal, vol 5, n² ${ }^{\circ}$, p.171-181.

Wils T., Labelle C., Guérin C., Tremblay M. (1998), Qu'est-ce que la mobilisation des employés ? Le point de vue des professionnels en ressources humaines, Gestion, vol.23, n², p. 30-39. 


\section{Skill-induced mobilization at work: a study of an activist group \\ Fabien HILDWEIN}

\section{Annex 1: interview guide for the activists}

First part: Bio and personality of the activist

- Ask the activist to introduce herself: age, occupation, origins

- Did she have prior experience?

- What experience of feminism did she have before?

- How did she join La Barbe and why?

- What has been her evolution within La Barbe?

- Does she plan on staying with La Barbe? (Question added in order to take into account departure decision of other groups and to better recount militant careers)

Second part: The sense of performance

- Ask her to describe fully one given performance/action

- If there are not enough explanations, why each element (hairpiece, banner, irony, etc.)?

- What is the feedback from the audience?

- If possible, ask her to describe a concrete action in which both the activist and the ethnographer took part

\section{Annex 2: List of press sources}

Sources of the articles collected on La Barbe between February 28, 2008 (creation of La Barbe) and November 19, 2013 (date of the research), i.e. 2077 days, by type of newspapers and by alphabetical order. (Between brackets, the number of articles published)..

- $\quad$ Generalist

- 20 Minutes (5)

- $\quad$ BFM (1)

- $\quad$ Direct Matin (5)

- $\quad$ Huffingtonpost (3)

- $\quad$ L'Humanité (6)

- $\quad$ L'Humanité Dimanche (1)

- $\quad$ La Croix (3)

- $\quad$ Le Figaro (2)

- $\quad$ Le Journal du Dimanche (2)

- $\quad$ Le Monde (3)

- $\quad$ Le Nouvel Observateur (1)

- $\quad$ Le Point (4)

- $\quad$ Les Inrocks (4)

- $\quad$ Les Nouvelles News (5)

- L'Express (3)

- Libération (9)

- $\quad$ M le magazine du Monde (1)

- Marianne (1)

- $\quad$ Mediapart.fr (2)

- $\quad$ Metronews (1)

- $\quad$ Rue89 (3) 
- Economic Press

- $\quad$ Alternatives économiques (3)

- Investir.fr (2)

- $\quad$ L'Entreprise (1)

- $\quad$ La Tribune (1)

- $\quad$ Les Echos (3)

- $\quad$ Stratégies (3)

- $\quad$ Local Press

- $\quad$ Centre Presse (2)

- $\quad$ Dimanche Ouest France (1)

- $\quad$ La Charente Libre (7)

- $\quad$ La Nouvelle République (4)

- $\quad$ La Voix du Nord (4)

- $\quad$ L'AGEFI Quotidien (1)

- $\quad$ Le Berry Républicain (1)

- $\quad$ Le Midi Libre (3)

- $\quad$ Le Parisien (14)

- $\quad$ Le Progrès (3)

- $\quad$ L'Est Républicain (2)

- $\quad$ L'Indépendant (6)

- Ouest France (11)

- $\quad$ Presse Océan (7)

- $\quad$ Sud Ouest (7)

- $\quad$ Tribune de Genève (1)

- $\quad$ Press Agencies

- $\quad$ AFP (51)

- $\quad$ Associated Press (2)

- $\quad$ ATS Information (2)

- $\quad$ Reuters (5)

- $\quad$ Foreign Press and specialized Press

- Acteurs Publics (1)

- $\quad$ ComTex (1)

- $\quad$ Grazia (2)

- $\quad$ La Correspondance de la Presse (1)

- $\quad$ La Gazette Santé Sociale (1)

- $\quad$ La Presse Canadienne (1)

- $\quad$ Le Matin (2)

- $\quad$ Rue $69(1)$

- $\quad$ Slate (3)

- $\quad$ The Times (1)

RIMHE - Revue Interdisciplinaire Management, Homme \& Entreprise $\mathrm{n}^{\circ} 26$ - Printemps 2017 